\title{
MODEL PENGENDAPAN RESERVOAR GITA INTERVAL 34-1, FORMASI TALANGAKAR, LAPANGAN WIDURI, CEKUNGAN ASRI
}

\author{
HERYANTI EFENDI, DONATUS HENDRA AMIJAYA, AND JAROT SETYOWIYOTO
}

\author{
Gadjah Mada University, Jurusan Teknik Geologi FT UGM, Jln. Grafika 2 Yogyakarta 55281 Indonesia, \\ Email: heryanti.efendi@gmail.com, hamijaya@ugm.ac.id,j_setyowiyoto@ugm.ac.id
}

\begin{abstract}
Sari - Interval 34-1 adalah reservoar terbesar ketiga di Lapangan Widuri, Cekungan Asri dengan produksi kumulatif mencapai 11 juta barel minyak dari 31 juta barel cadangan minyak awal. Belum pernah dilakukan analisis fasies secara menyeluruh pada Interval 34-1, reservoar batupasir Gita, Formasi Talangakar, Lapangan Widuri. Model pengendapan reservoar pada penelitian ini dibangun melalui pemahaman fasies litologi dan sistem pengendapan sehingga secara geologi diharapkan mendekati kondisi sebenarnya. Data yang digunakan dalam penelitian ini adalah data analisis batuan inti dari 3 sumur dengan panjang total 485 kaki, data log sumur dari 7 sumur produksi dan 1 sumur eksplorasi, data petrografi dan XRD, data biostratigrafi dan paleobatimetri, dan peta atribut seismik impendansi akustik. Pada model pengendapan reservoar Interval 34-1 berkembang endapan supratidal marsh/swamp di bagian bawah. Fase pertama transgresi menghasilkan endapan shallow marine, diikuti endapan estuary channel pada periode pertama regresi. Fase kedua transgresi mengendapkan intertidal flat, diikuti endapan shallow marine pada periode ketiga transgresi.
\end{abstract}

Kata kunci: Reservoar Gita, Cekungan Asri, fasies, asosiasi fasies, model pengendapan.

\begin{abstract}
The Interval 34-1 is the third largest reservoir in the Widuri Field, Asri Basin with cumulative production reaching 11 Million Metric Barrels of Oil from 31 MMBO Original Oil in Place. There has never been a thorough facies analysis at The Interval 34-1, Gita sandstone reservoir, Talangakar Formation, The Widuri Field. The reservoir deposition model in this research built through the understanding of lithology facies and settling system so that geology condition is expected to be close to the actual. The data used in this study are core rock analysis data from 3 wells with a total length of 485 feet, well log data from 7 production wells and 1 exploratory well, petrography and XRD data, biostratigraphy and paleobathymetry data, and map of acoustic impendance seismic attribute. In the reservoir deposition model of The Interval 34-1 developed supratidal marsh/swamp at the bottom. The first transgression phase resulted in the deposition of shallow marine deposit, followed by estuary channel deposit at the first regression period. The second transgression produced intertidal flat deposit, followed by shallow marine deposit in the third transgression period.
\end{abstract}

Keywords: The Gita Reservoir, The Asri Basin, facies, facies associations, depositional model.

\section{PENDAHULUAN}

Objek penelitian ini adalah reservoar batupasir Gita, Formasi Talangakar, Lapangan Widuri Cekungan Asri (Gambar 1) yang terletak di bagian barat Laut Jawa, sekitar $180 \mathrm{~km}$ di utara lepas pantai utara Pulau Jawa bagian barat dan sekitar $140 \mathrm{~km}$ di timur lepas pantai tenggara Pulau Sumatra. Belum pernah dilakukan analisis fasies secara menyeluruh pada setiap interval reservoar batupasir Gita, Formasi Talangakar.

Penelitian ini bertujuan untuk menentukan fasies litologi dan lingkungan pengendapan serta mendapatkan model pengendapan reservoar Gita Interval 34-1, Formasi
Talangakar, Lapangan Widuri, Cekungan Asri.

Cekungan Asri dibatasi oleh Paparan Sunda di bagian utara, di sebelah timur dibatasi oleh Cekungan Biliton dan Busur Karimun Jawa, di sebelah selatan dibatasi oleh Cekungan Jawa Barat dan Platform Seribu, dan di bagian barat dibatasi oleh Tinggian Lampung. Cekungan ini memiliki luas sekitar $3500 \mathrm{~km}^{2}$ dengan ketebalan sedimen mencapai 16.000 kaki yang terbentuk pada Paleosen sampai Pleistosen (Sukanto dkk, 1998). Lapangan minyak pada Cekungan Asri didominasi oleh perangkap struktural dan kombinasi antara perangkap stratigrafi dan struktural (Young dkk, 1991). 


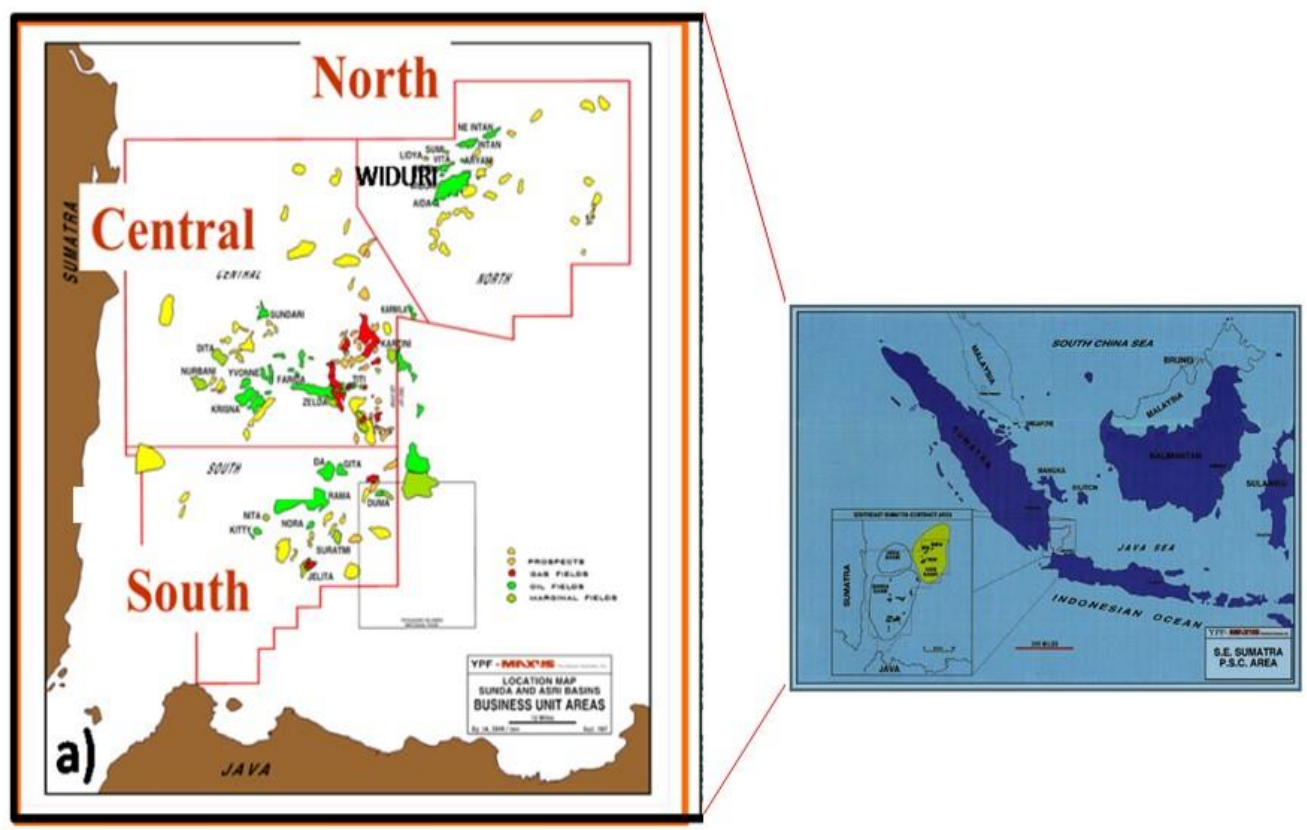

Gambar 1. Peta lokasi Lapangan Widuri, Cekungan Asri (Sukanto dkk, 1998).

Secara tektonik, Formasi Talangakar Anggota Gita diendapkan pada periode post rift kala Miosen Awal (Gambar 2). Pada periode ini proses pemekaran telah berhenti, dan terjadi penurunan cekungan dan transgresi laut yang bersifat regional. Neogen post-rift dimulai dengan transgresi air laut, ditandai oleh diendapkannya batuan pada lingkungan laut (Sukanto dkk, 1998).

Penelitian terdahulu dilakukan oleh Exploration Think Tank Indonesia (ETTI), 2008. ETTI melakukan penelitian untuk mengetahui variasi fasies secara lateral dan vertikal serta sistem pengendapan pada semua zona produksi di Reservoar Gita Formasi Talangakar, Lapangan Widuri, Cekungan Asri.

Peta fasies berdasarkan perhitungan metode cut-off menunjukkan fasies dominan pada batupasir Interval 34-1 adalah endapan tidal channel berarah baratlaut-tenggara. Distribusi fasies pada interval ini tidak terkoneksi.
Penelitian lain dilakukan oleh Kusuma (2010) yang melakukan karakterisasi reservoar 34-1E berupa analisis fasies dan kompartementalisasi di Lapangan Widuri, Cekungan Asri, Sumatera Selatan Bagian Tenggara. Hasil deskripsi data batuan inti dan korelasi antar sumur mengidentifikasi tiga macam fasies pada reservoar 34-1E yaitu Estuarine Channel, Tidal Sand Flat dan Tidal Mud Flat. Kusuma (2010) menyimpulkan bahwa reservoar Interval 34-1E adalah reservoar batupasir amalgamasi yang memiliki heterogenitas arsitektur fasies bersifat penghalang yang menyebabkan reservoar ini terbagi-bagi menjadi beberapa kompartemen yang tidak saling terhubung satu sama lain.

Gunawan (2013) melakukan karakterisasi "rock type" reservoar batupasir Interval 34-2 Formasi Talangakar, Lapangan Widuri, Cekungan Asri. Pemahaman karakterisasi reservoar dilakukan dengan pengamatan data batuan inti melalui analisis litofasies, asosiasi fasies dengan pendekatan dan hubungannya dengan sifat-sifat petrofisika batuan yang diperoleh dari pengukuran laboratorium. 


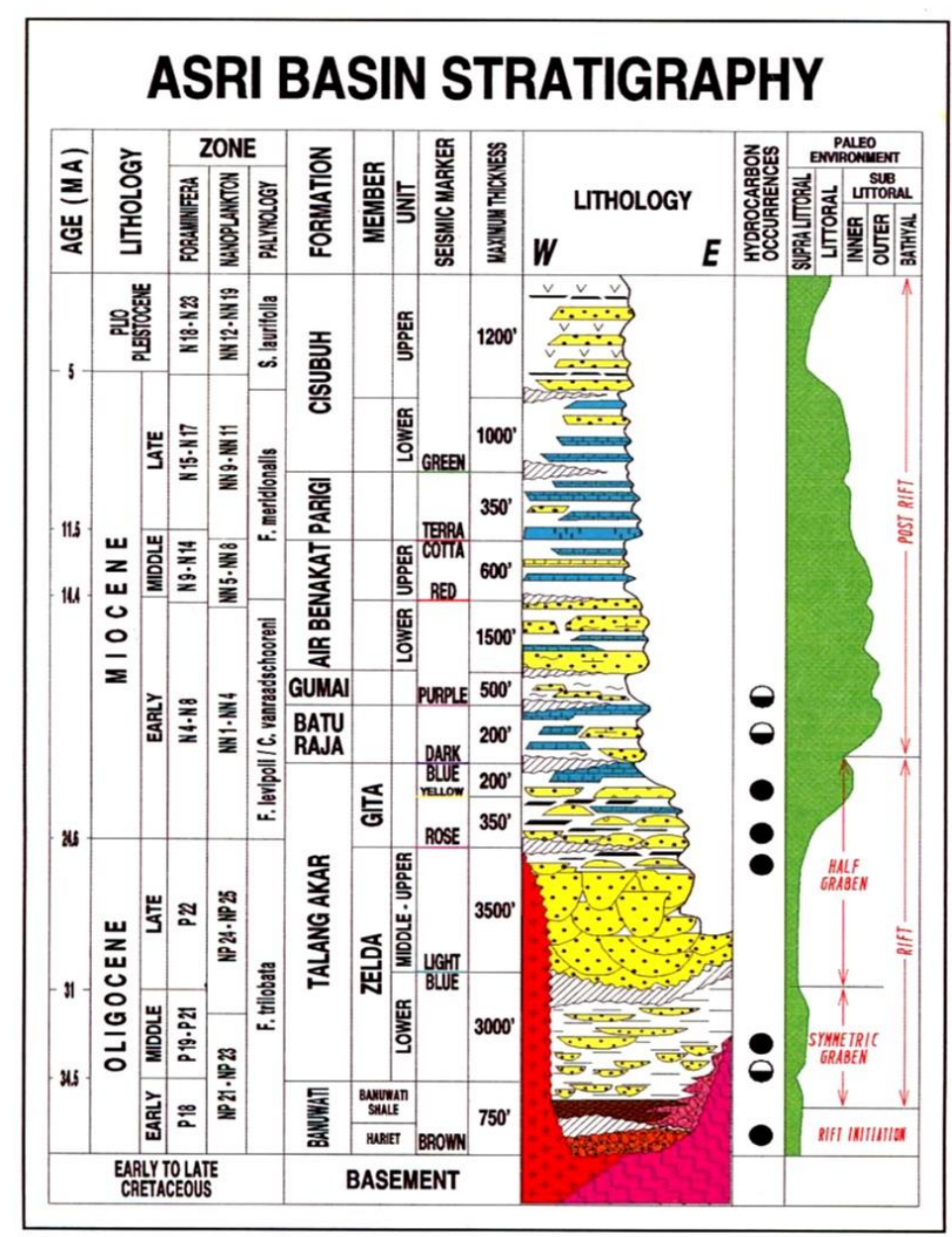

Gambar 2. Kolom Stratigrafi Regional Cekungan Asri (Sukanto dkk, 1998).

Penelitian ini membangun model pengendapan reservoar melalui pemahaman fasies litologi dan sistem pengendapan sehingga secara geologi diharapkan mendekati kondisi sebenarnya. Model pengendapan dibangun dengan melakukan analisis data meliputi analisis fasies, identifikasi litofasies, dan asosiasi fasies dari data batuan inti (3 sumur), data $\log$ ( 7 sumur produksi dan 1 sumur eksplorasi), biostratigrafi, paleobatimetri, petrografi dan XRD dipandu oleh peta atribut seismik Interval 34-1 (data sekunder).

\section{METODOLOGI PENELITIAN}

Penelitian didahului dengan melakukan studi pustaka area penelitian dan mencermati permasalahan yang ada. Pada tahapan ini dilakukan pengumpulan data yang diperlukan untuk analisis meliputi data geologi regional, sumur, batuan inti, seismik, biostratigrafi, dan paleobatimetri. Penelitian dilanjutkan dengan melakukan analisis data meliputi analisis asosiasi fasies Interval 34-1 dan sekitarnya.
Korelasi data log sumur dilakukan beriringan dengan analisis asosiasi fasies. Hasil analisis asosiasi fasies bersama hasil korelasi log sumur dipandu peta atribut seismik digunakan untuk membuat model pengendapan Interval 34-1. Tahapan terakhir adalah pembahasan dan interpretasi data yang dihasilkan dari model pengendapan yang diperoleh sebelumnya.

Perangkat lunak yang digunakan dalam penelitian ini adalah:

a. Geoframe yang digunakan untuk melakukan pembacaan peta atribut seismik dan plot posisi sumur pada peta dasar.

b. Petrel 2014 yang digunakan untuk melakukan korelasi sumur.

c. Perangkat lunak Corel Draw X7 untuk menggambar model pengendapan.

Prosedur analisis data diawali dengan melakukan identifikasi litofasies berdasarkan observasi data batuan inti, petrografi dan XRD. Observasi batuan inti dilakukan untuk 
mencermati struktur dan tekstur sedimen serta ukuran butir pada tiap litofasies. Pengamatan data biostratigrafi untuk mengetahui lingkungan terbentuknya litofasies berdasarkan fosil-fosil yang ditemukan. Sementara data paleobatimetri diperlukan untuk mengkonfirmasi kondisi pasang surut pada zona transisi dimana litofasies ini diendapkan.

Tahapan pertama analisis asosiasi fasies adalah analisis elektrofasies dengan membaca pola respon log GR dan melakukan pengelompokkan litofasies penyusun asosiasi fasies. Tahap selanjutnya adalah mengamati suksesi vertikal yang ditandai oleh kontak antar batuan dan pergerakan kurva paleobatimetri. Tahap terakhir analisis asosiasi fasies adalah mempelajari mekanisme transportasi sedimen untuk mengetahui energi pengendapan, dan mengamati struktur sedimen dan fosil yang ditemukan dalam kaitannya untuk memprediksi lingkungan pengendapan asosiasi fasies ini di masa lampau.

Korelasi log sumur dilakukan untuk menghubungkan unit stratigrafi yang memiliki kesamaan waktu pada area penelitian. Korelasi log diawali dengan melakukan penyamaan datum (flatten) antara satu sumur dengan sumur lainnya. Korelasi dilakukan dengan mengamati litologi penciri masing-masing batuan dengan membaca pola log sinar gamma dan log-log lain dikalibrasi dengan informasi dari data batuan inti.

Tahap pembuatan model pengendapan mengintegrasikan peta penyebaran atribut seismik dengan analisis asosiasi fasies. Lintasan korelasi penampang relatif berarah barat laut-tenggara dan utara-selatan mengikuti penyebaran atribut kuat refleksi yang mencerminkan penyebaran batupasir Interval 34-1. Kedua penampang korelasi ini kemudian digunakan untuk mengetahui urut-urutan peristiwa dan mekanisme pengendapan reservoar Interval 34-1 yang akan diinterpretasikan dalam prediksi model pengendapan secara 2D pada Lapangan Widuri sekitar area penelitian.

\section{HASIL DAN PEMBAHASAN}

Interpretasi fasies didukung oleh analisis data batuan inti dari tiga sumur (IA-06, W-01, dan WB-08) dengan panjang total 485 kaki yaitu 213 kaki data batuan inti sumur IA-06, 36 kaki sumur W-01, dan 236 kaki sumur WB-08. Klasifikasi fasies yang dibuat oleh Miall (1978) digunakan dalam identifikasi litofasies di Lapangan Widuri. Ada sepuluh litofasies yang dianalisis pada penelitian ini (Gambar 3); lima litofasies berasosiasi dengan batuan reservoar yaitu; litofasies batupasir berbutir halus - sangat halus planar cross bedding (Sp);

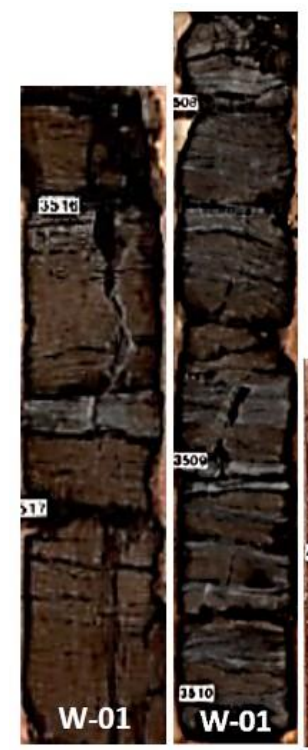

(a) (b)

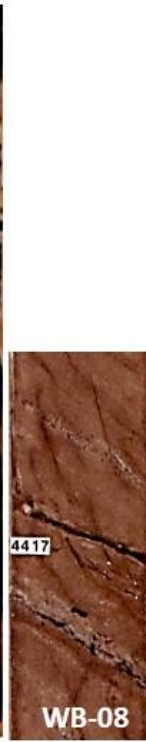

(c)

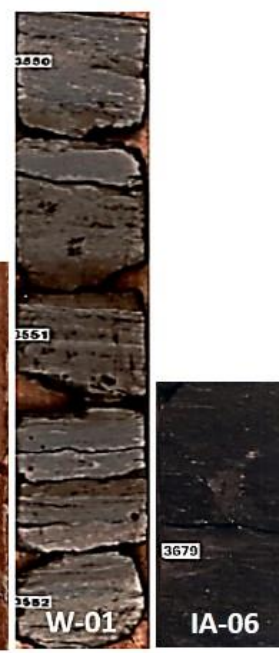

(d) (e)

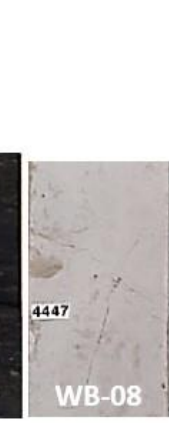

(f)

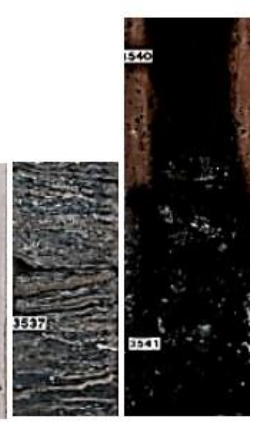

(g)

(h)

Gambar 3. Litofasies (a) Sp, (b) Sf, (c) St, (d) Fl, (e) Fc, (f) Fcf, (g) Lm, dan (h) C. 
litofasies batupasir berbutir halus - sangat halus flaser (Sf), litofasies batupasir berbutir halus sangat halus bioturbasi (Sb), litofasies batupasir berbutir halus - sangat halus ripple (Sr), litofasies batupasir berbutir halus trough cross-bedding (St) dan lima litofasies yang berasosiasi dengan batuan non reservoar yaitulitofasies batulempung lenticular $(\mathrm{Fl})$, litofasies batulempung karbonan $(\mathrm{Fc})$, litofasies batulanau masif (Fcf), litofasies batugamping (Lm), dan litofasies batubara (C).

Identifikasi asosiasi fasies pada penelitian ini mengacu pada sistem coastal-plain estuaries oleh Walker dan James (1992) dan estuari macrotidal atau open-ended Gironde oleh Allen (1991) serta sistem tide-dominated estuaries oleh Dalrymple dkk (1992) dalam Nichols (2009).
Pada asosiasi fasies estuarine point bar, kurva paleobatimetri menunjukkan bahwa secara umum terjadi proses regresi berupa pergerakan garis pantai menuju laut dangkal. Asosiasi fasies ini tersusun atas litofasies $\mathrm{Sp}, \mathrm{Sb}, \mathrm{Sr}, \mathrm{Sf}$, dan St. Respon sinar gamma menunjukkan pola lonceng (bell shape) yang dicirikan oleh endapan sedimen yang menghalus ke atas yang menandai semakin berkurangnya energi pengendapan ke arah atas (Gambar 4). Kontak erosional tajam dengan struktur sedimen trough cross bedding mencirikan pola bimodal paleocurrent, sementara wavy-flaser bedding menunjukkan pembentukan oleh arus maksimum saat pasang surut dominan. Bioturbasi dari burrow Thalassinoides dan Teichichnus (ichnofacies Skolithos dan Cruziana) menunjukkan lingkungan pesisir (coastal).
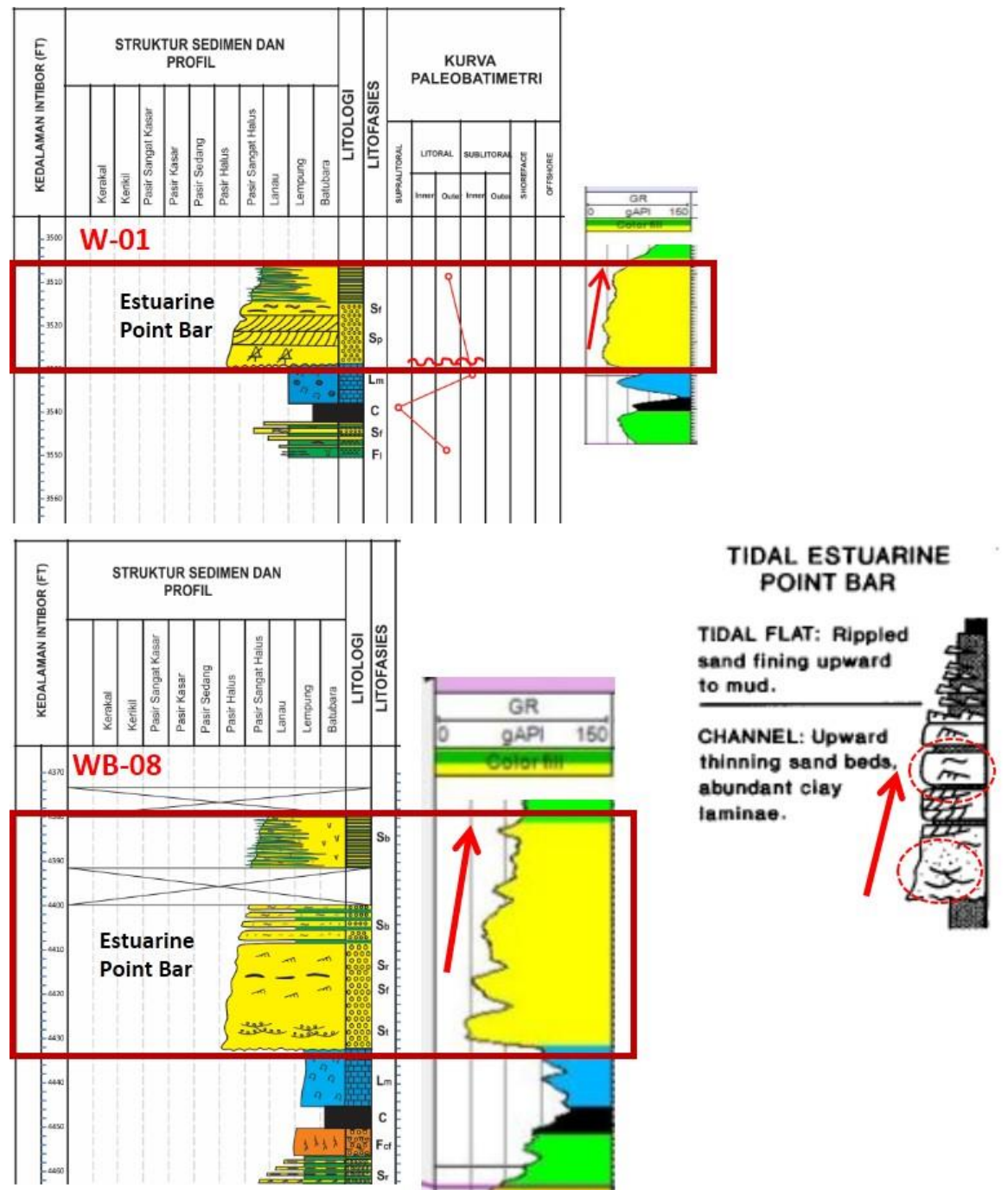

Gambar 4. Asosiasi fasies estuarine point bar pada siklus 34-1 di sumur W-01 dan WB-08 yang mendekati ilustrasi suksesi fasies pada estuari microtidal Gironde (Allen, 1991). 
Asosiasi fasies shallow marine tersusun oleh litofasies Lm. Pada asosiasi fasies ini dijumpai skeletal grain berupa cangkang, koral, foraminifera dan planktonik, juga burrow Thalassinoides, Teichichnus yang merupakan ichnofacies Skolithos dan Cruziana yang menandai zona sublitoral pada lingkungan pengendapan laut dangkal. Suksesi vertikal pada asosiasi fasies ini berupa kontak basal antara batubara dan batugamping dengan kurva paleobatimetri menunjukkan pergerakan garis pantai ke arah daratan (Gambar 5).
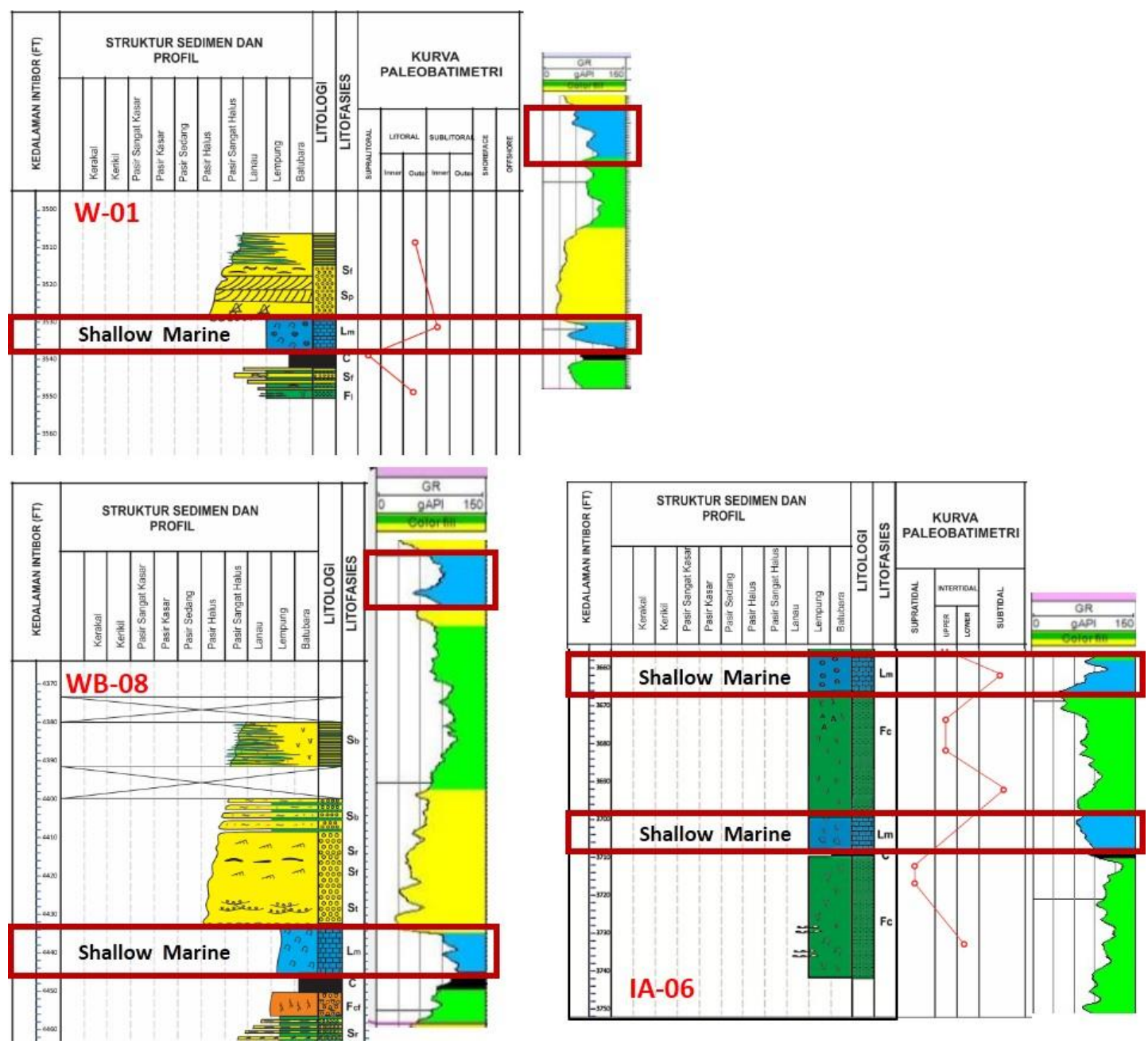

Gambar 5. Asosiasi fasies shallow marine pada siklus 34-1.

Asosiasi fasies marsh/swamp (Gambar 6) tersusun oleh litofasies batulempung karbonan (Fc) dan batubara (C). Asosiasi fasies ini didominasi oleh material karbon, fragmen batubara dan Amber yang terbentuk pada lingkungan pengendapan berenergi rendah.

Asosiasi fasies intertidal flat tersusun oleh litofasies Fcf, Fl, Fc, Sr, dan Sf. Respon log GR pada asosiasi fasies intertidal flat berpola menghalus ke atas (sand shale ratio mengecil) di bagian bawah dan mengkasar ke atas di bagian atas. Suksesi vertikal berupa proses transgresi dan regresi (Gambar 7). Transgresi ditandai dengan pergerakan dari zona outer- litoral ke zona supralitoral. Regresi ditandai dengan kontak antara batugamping dan batubara berupa pergerakan dari laut dangkal ke arah daratan. Struktur sedimen yang dijumpai adalah struktur sedimen rooted, flaser bedding, ripple-wavy bedding, dan lenticular bedding yang merupakan tipikal dari endapan intertidal flat.

Data batuan inti digunakan untuk membantu analisis litofasies dan asosiasi fasies. Sementara untuk memprediksi geometri dan model pengendapan, selain analisis asosiasi fasies diperlukan integrasi data atribut seismik dan korelasi log sumur. 

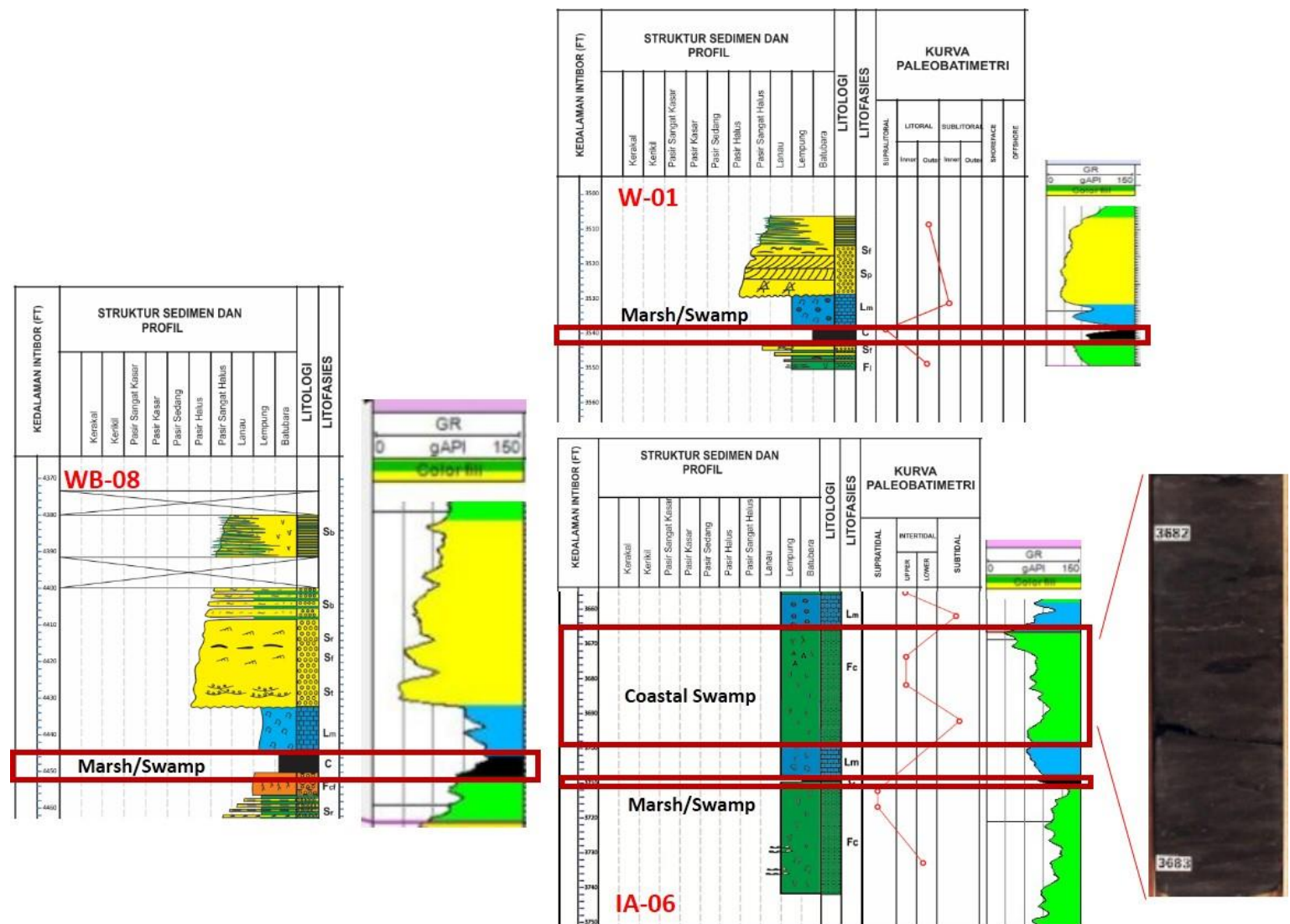

Gambar 6. Asosiasi fasies marsh/swamp siklus 34-1 pada sumur IA-06, W-01, dan WB-08.

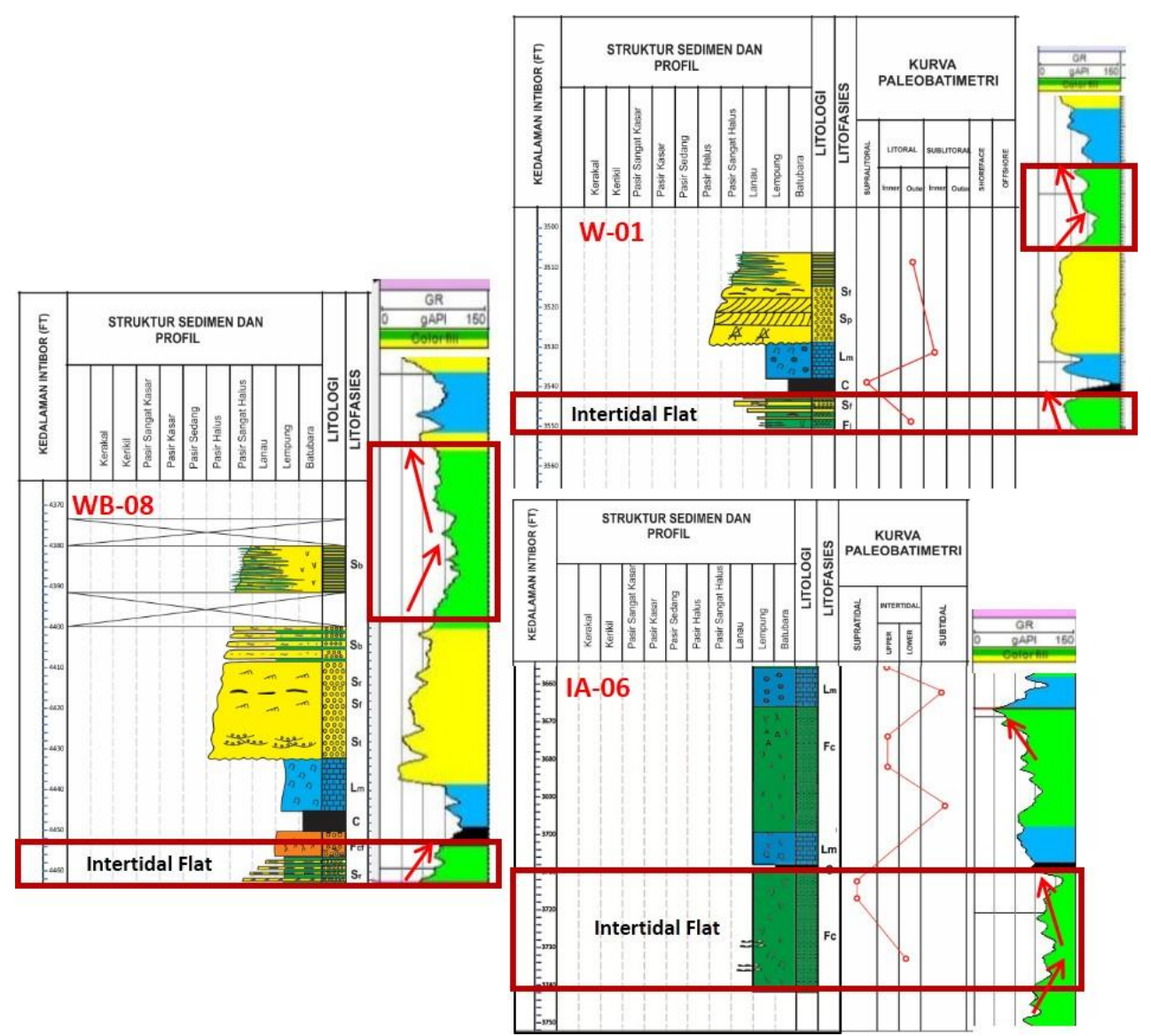

Gambar 7. Asosiasi fasies intertidal flat pada siklus 34-1. 
Berdasarkan peta penyebaran atribut seismik dengan korelasi log sumur-sumur yang telah dianalisis asosiasi fasies-nya, dibuat penampang korelasi stratigrafi yang melewati sumur-sumur tersebut. Penampang korelasi berarah relatif baratlaut - tenggara $\mathrm{AB}$ (Gambar 8) dan utara - selatan CD (Gambar 9). Kedua penampang ini didatarkan pada $T o p$ Shale 1 yang terletak di atas Interval 34-1 untuk mendapatkan paleogeografi pada sistem siklus 34-1 diendapkan. Penampang stratigrafi ini menampilkan adanya penebalan pada sumur W-01, WB-08, WC-06, dan WH-11i yang terisi oleh endapan estuary channel. Struktur paleo low pada batubara menjadi ruang akomodasi untuk suplai sedimen yang mengisi channel.

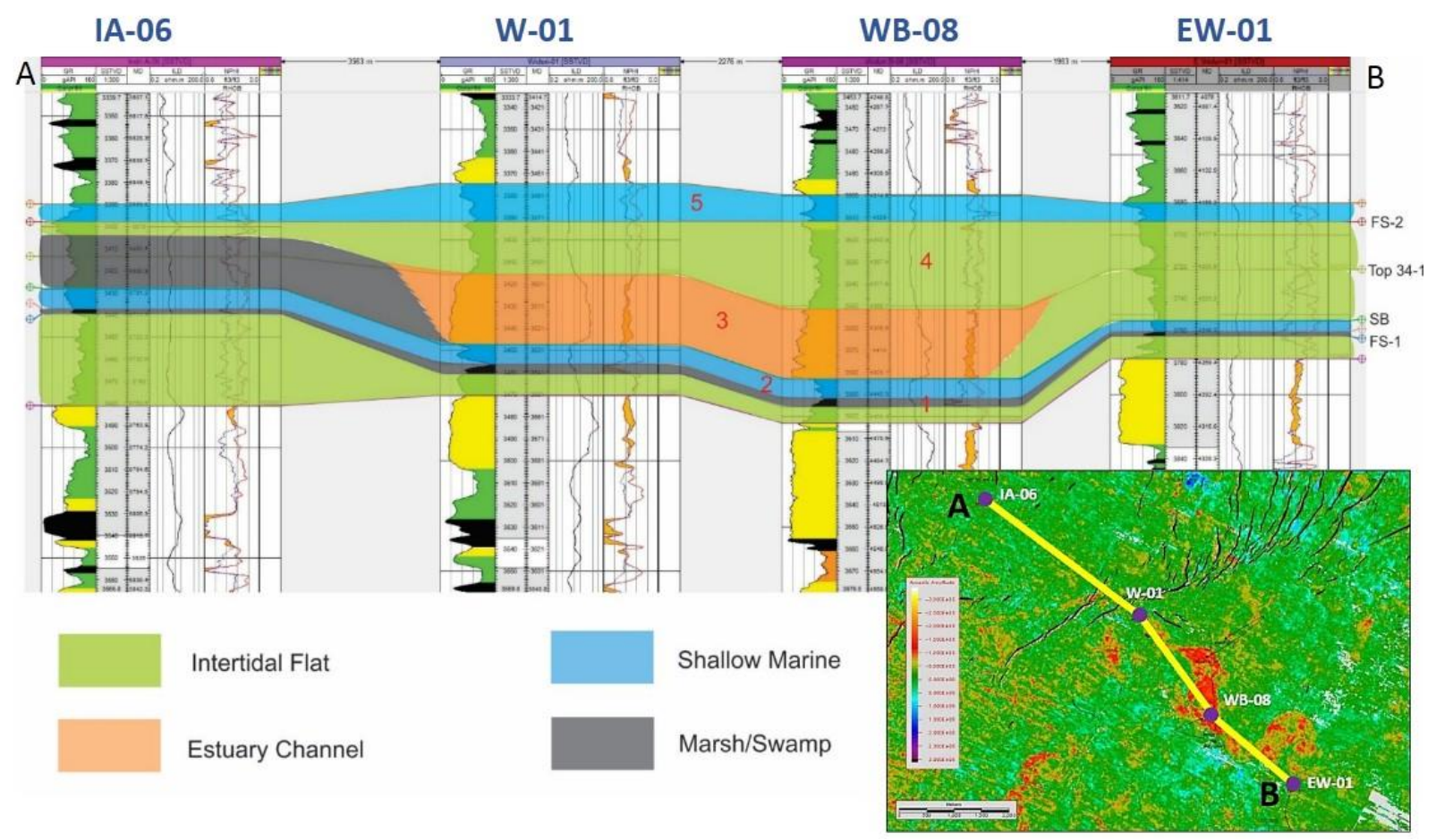

Gambar 8. Penampang korelasi stratigrafi Interval 34-1 berarah relatif baratlaut-tenggara (AB).

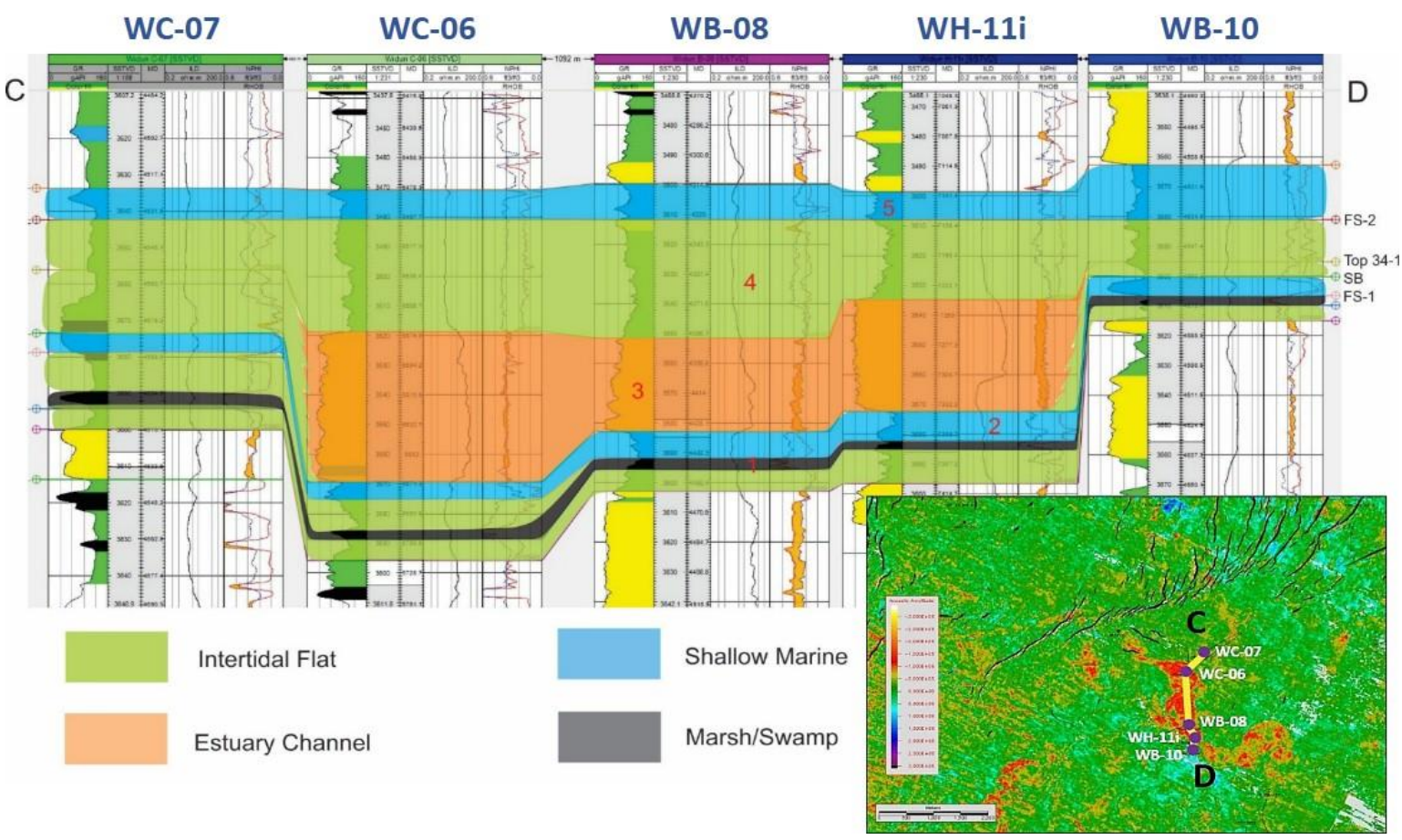

Gambar 9. Penampang korelasi stratigrafi Interval 34-1 berarah relatif utara-selatan (CD). 
Suksesi vertikal pada Interval $34-1$ berupa siklus transgresi - regresi reservoar Interval 34-1. Siklus ke-1 pada suksesi vertikal reservoar Interval 34-1 adalah periode regresi pertama yang berakibat berubahnya lingkungan pengendapan dari lingkungan laut dangkal menjadi lingkungan rawa-rawa. Endapan pada siklus ke-1 ini adalah endapan

(a)

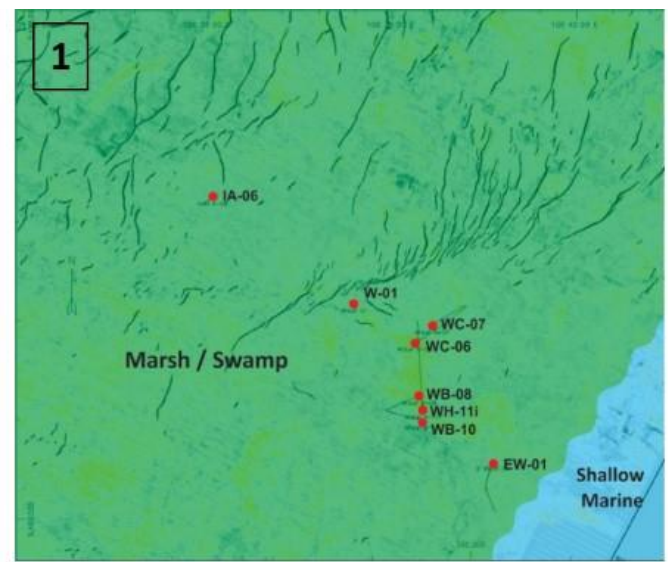

supratidal marsh/swamp berupa batubara yang merupakan hasil sedimentasi dari proses transgresi (warna hijau pada Gambar 10a). Batubara (C) melampar secara meluas dan menjadi marker yang mengindikasikan adanya perubahan unit genesa secara signifikan. Pada penampang $\mathrm{C}-\mathrm{D}$, endapan batubara onlapping terhadap endapan estuary channel.

(c)
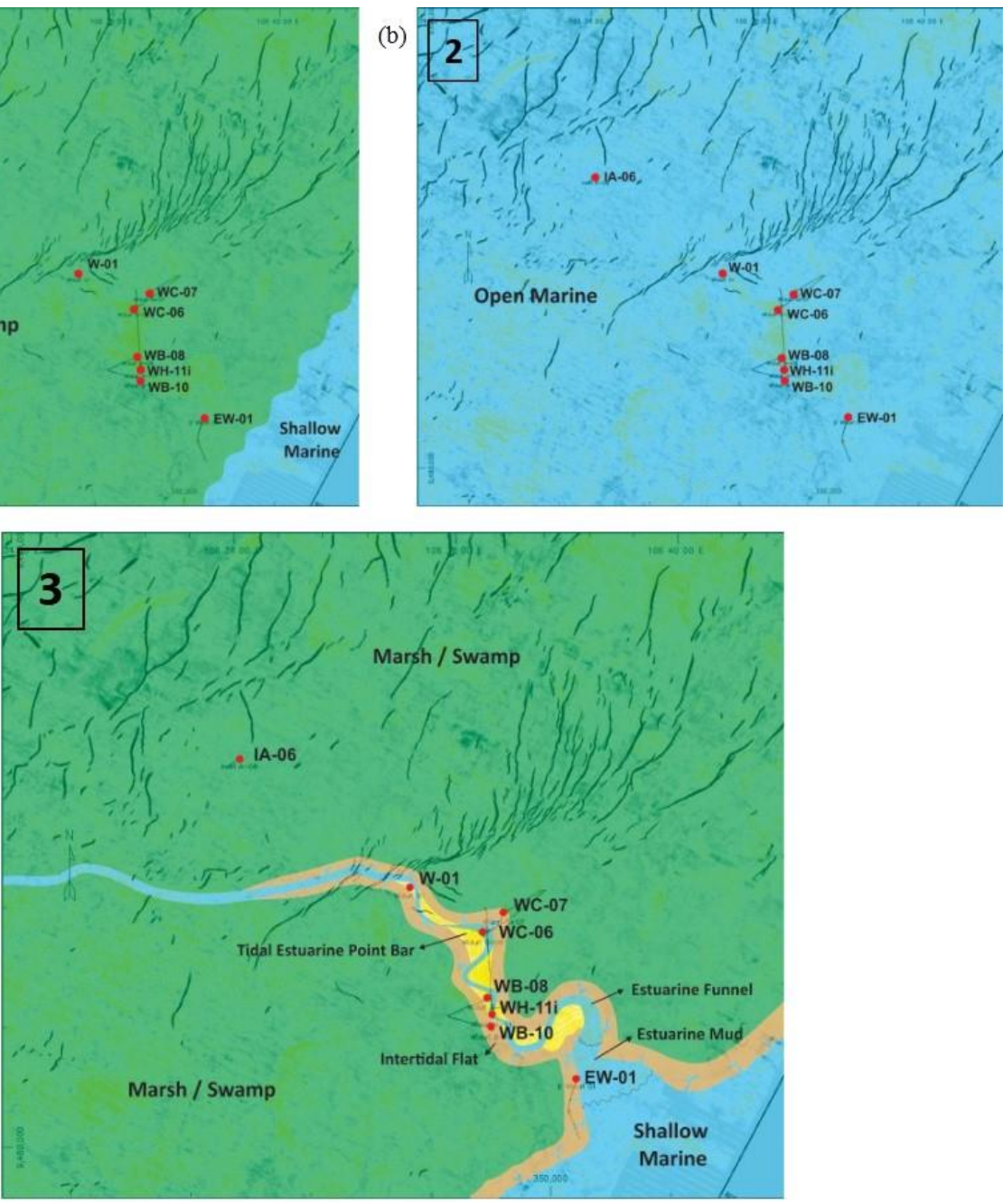

(d)

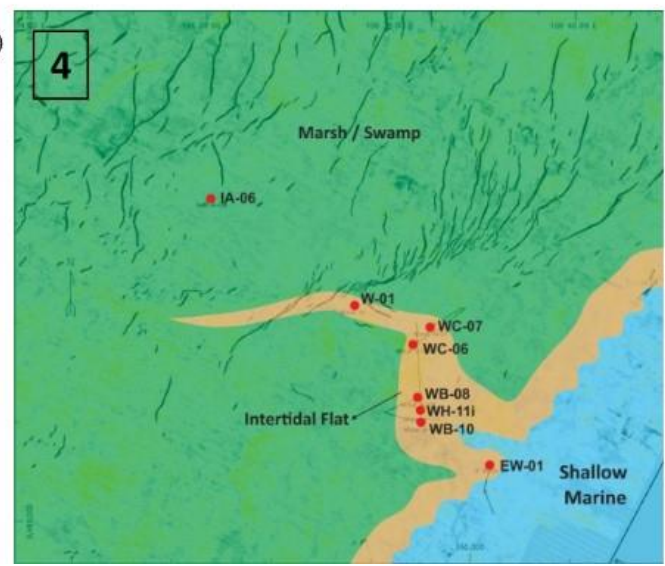

(e)

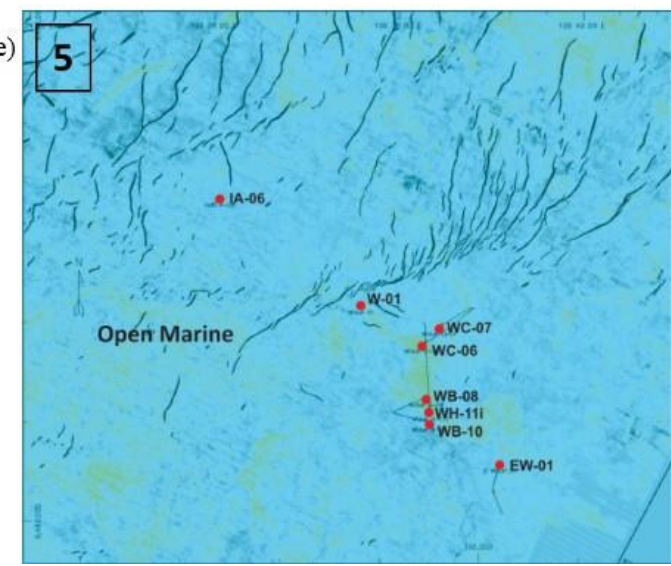

Gambar 10. (a) Model pengendapan pada; (a) siklus ke-1, (b) siklus ke-2 (c) siklus ke-3, (d) siklus ke-4, dan (e) siklus ke-5; Interval 34-1. 
Siklus ke-2 pada suksesi vertikal reservoar Gita Interval 34-1 ditandai dengan peristiwa transgresi pertama. Siklus ini menandai permukaan permukaan banjir pertama (FS-1). Sedimen yang terendapkan pada siklus ini adalah endapan laut dangkal berupa packstone yang tersusun oleh fragmen cangkang, foraminifera, dan planktonik penanda endapan lingkungan laut dangkal (warna biru pada Gambar 10b).

Siklus ke-3 pada suksesi vertikal Interval 34-1 adalah periode regresi kedua yang menyisakan ruang akomodasi untuk terendapkannya sedimen estuary channel. Siklus ini menandai batas ketidakselarasan yaitu Sequence Boundary (SB) yang ditunjukkan oleh perubahan tiba-tiba asosiasi fasies shallow marine menjadi asosiasi fasies estuarine point bar. Pada penampang AB (Gambar 8), endapan estuary channel dijumpai pada sumur W-01 dan WB-08. Semakin ke arah baratlaut, dijumpai endapan supratidal marsh/swamp yang terendapkan pada periode pengendapan yang sama dengan endapan estuary channel. Proses regresi menyisakan zona supratidal yaitu zona dengan level pasang tinggi pada area sumur IA-06 berupa daerah rawa-rawa yang membentuk endapan batubara. Semakin ke arah tenggara adalah ke arah laut; zona di antara level pasang rendah dan tinggi; endapan yang terbentuk adalah endapan intertidal flat berupa sedimen batulempung, batupasir, batulanau dengan struktur wavy, ripple, flaser bedding yang dominan di area intertidal. Pada penampang korelasi CD (Gambar 9), endapan estuary channel dijumpai pada sumur WC-06, WB-08, dan WH-11i. Ketiga sumur ini terletak di zona kuat refleksi tinggi dari peta atribut seismik. Sementara di sebelah utara dan selatan endapan estuary channel, endapan yang dijumpai adalah intertidal flat (warna coklat pada Gambar 10c) yang ditandai dengan endapan sedimen batulempung pada sumur WC-07 dan WB-10. Model pengendapan siklus ke-3 suksesi vertikal reservoar Interval 34-1 ini menampilkan estuarine funnel dari suatu sistem estuari dengan area rawa-rawa (warna hijau) mengapit estuari. Endapan estuarine point bar yang merupakan bagian dari tidal channel dan endapan intertidal flat menunjukkan dominasi pasang surut pada sistem estuari di area penelitian ini (Gambar 10c).

Siklus ke-4 adalah periode naiknya kembali muka air laut (periode transgresi kedua) yang menjelaskan terendapkannya endapan intertidal flat pada penampang A-B dan C-D. Di sisi baratlaut penampang A-B, endapan yang dijumpai adalah endapan supratidal marsh/swamp berupa endapan batubara (Gambar 10d).

Siklus ke-5 pada suksesi vertikal reservoar Gita Interval 34-1 ditandai dengan terus naiknya muka air laut (periode transgresi ketiga) sehingga dijumpai endapan laut dangkal yang melampar secara horisontal (Gambar 10e). Siklus ini menandai permukaan FS-2 yang ditandai oleh banjir berikutnya pada periode pengendapan ini.

\section{KESIMPULAN}

Kesimpulan dari penelitian ini adalah:

1. Fasies litologi reservoar Gita Interval 34-1 adalah batupasir halus-sangat halus dengan litofasies yang berbeda-beda yaitu litofasies batupasir berbutir halus - sangat halus planar cross bedding (Sp), litofasies batupasir berbutir halus - sangat halus flaser (Sf), litofasies batupasir berbutir halussangat halus bioturbasi (Sb), litofasies batupasir berbutir halus - sangat halus ripple (Sr), dan litofasies batupasir berbutir halus trough cross-bedding ( $\mathrm{St}$ ). Empat asosiasi fasies yang teridentifikasi pada reservoar Gita Interval 34-1 di Lapangan Widuri ini adalah Estuarine Point Bar, Shallow Marine, Marsh/Swamp, dan Intertidal Flat yang diendapkan pada lingkungan pengendapan estuari.

2. Model pengendapan reservoar Gita Interval 34-1 di bagian bawah berkembang endapan supratidal marsh/swamp. Fase transgresi pertama menghasilkan diendapkannya endapan shallow marine, diikuti endapan estuary channel pada periode regresi kedua. Periode transgresi kedua menghasilkan endapan intertidal flat, diikuti endapan shallow marine pada periode transgresi ketiga. 
UCAPAN TERIMA KASIH

Terima kasih kepada CNOOC SES Ltd. atas fasilitas dan ijin penggunaan data dalam penelitian ini.

\section{REFERENSI}

Allen, G.P., 1991: Sedimentary Processes and Facies in The Gironde Estuary: A Model for Macrotidal Estuary Systems dalam Smith, D.G, Reinson, G.E., Zaitlin, B.A. and Rahmani, R.A., eds., Clastic Tidal Sedimentology: Canadian Society of Petroleum Geologist, 16, 219-226.

Exploration Think Tank Indonesia (ETTI), 2008, Final Report of Widuri Detailed Facies Description and Analysis, 131 Hal.

Gunawan, H., 2013, Karakterisasi "Rock Type" Reservoar Batupasir Interval 34-2 Formasi Talangakar, Lapangan Widuri, Cekungan Asri, Institut Teknologi Bandung, 77 Hal.
Kusuma, Y. R., 2010, Karakteristik Reservoar 34-1E: Analisis Fasies dan Kompartementalisasi, Lapangan Widuri, Cekungan Asri, Sumatera Selatan Bagian Tenggara, Institut Teknologi Bandung, 46 Hal.

Miall, A.D., 1978, Facies type and vertical profile models in braided river deposits, Canadian Society of Petroleum Geologists, 5, 597-604.

Nichols, G., 2009, Sedimentology and Stratigraphy $\left(2^{\text {nd }}\right.$ edition $), \quad$ WileyBlackwell, 432 Hal.

Sukanto, J., F, Nunuk., Aldrich, J.B., Rinehart, G.P., Mirchell, J., 1998, Petroleum System of the Asri Basin, Java Sea, Indonesia, Proceeding IPA $26^{\text {th }}$ Annual Convention, Jakarta, 291-312.

Walker, R.G., James, N.P., 1992, Facies Models - Response to Sea Level Change, Geological Association of Canada, 179-191. 